\title{
Investigation Process on Criminal Actions of Corruption of Village Fund
}

\author{
Siswo De Cuellar Tarigan ${ }^{*}$ and Sukarmi*)
}

*) Student of Masters (S2) of Law Faculty of Law Unissula email: Tasimalaya, email: trg.41ah@gmail.com

**) Faculty of Law Universitas Islam Sultan Agung

\begin{abstract}
.
The purpose of this research To analyze processes investigation of the corruption crime of village funds in Tasikmalaya Regency, which encountered in investigating the corruption crime of village funds in Tasikmalaya Regency, To analyze what solutions investigators took in overcoming obstacles encountered in investigating criminal acts of village fund corruption in Tasikmalaya Regency. The approach method used is juridical normative and juridical socio-logical method, the specifications in the research are descriptive analytical, population and sampling methods are all objects or all symptoms or all events or all units to be studied, data collection techniques use literature study and interviews, data analysis used is qualitative. Research results: Proses investigating the corruption crime of village funds in Tasikmalaya Regency with the existence of a report, the Police carried out a series of investigative actions to find and find an event that was suspected of being a criminal act of corruption in order to determine whether or not an investigation could be carried out in a manner regulated by law. After an investigation is carried out and a criminal act of village fund corruption is found, it is upgraded to an investigation, namely a series of actions by the investigator in terms and according to the manner stipulated in law to seek and collect evidence, which with this evidence makes clear about the criminal act of fund corruption, village that happened and in order to find the suspect. The investigation process extended detention, searches and confiscations. Obstacles faced in carrying out criminal investigations at the Tasikmalaya Police: The suspect did not provide clear information, the witness's statement did not support the implementation of the investigation and the evidence to be submitted was incomplete. Efforts made in overcoming obstacles are as follows: The suspect must provide honest and clear information to the investigator regarding the sequence of events and objects of the criminal act of corruption and where it can be used as evidence to reveal criminal acts of corruption in village funds, Witnesses must be able to cooperate with investigators in provide honest and complete information, making it easier for investigators to uncover criminal acts of village fund corruption, Investigators must be able to find and collect evidence, at least 2 (two) pieces of evidence.
\end{abstract}

Keywords: Investigation; Corruption; Village Funds.

\section{Introduction}

Investigation is the most important stage in the framework of criminal procedure law in Indonesia, because at this stage the investigator seeks to uncover facts and evidence of the occurrence of a criminal act and find the suspect who is the perpetrator of the crime. The Criminal Procedure Code (KUHAP) as formulated gives the intention of investigators to be people conducting investigations consisting of officials, namely Indonesian National Police Officers (POLRI) who are 
divided into full investigating officers and assistant investigating officers, as well as Civil Servant Officials certain who are given special authority by law.

Prior to the commencement of an investigative process, the investigator has first carried out the stage of the investigation process. In Article 1 point 5 of Act No. 8 of 1981 concerning Criminal Procedure Law (KUHAP), it is stated that the meaning of investigation is as follows: "An investigation is a series of actions by an investigator to search for and discover an event that is suspected of being a criminal act in order to determine whether or not an investigation can be carried out in a manner regulated by this law". ${ }^{1}$

From this understanding, it can be seen that an investigation is an act of the first stage at the start of an investigation, but at the investigation stage the emphasis is placed on the act of searching for and finding an event that is considered or suspected to be a criminal act.

Whereas in the investigation process the emphasis is placed on the emphasis on finding and gathering evidence so that and so that the criminal acts found can be clear and in order to find and determine the perpetrators. There is almost no difference in meaning between the two (investigation and investigation). Between investigation and investigation are interrelated and complementary in order to complete the investigation of a criminal incident. ${ }^{2}$

One of the criminal events or criminal acts of corruption is the enemy of all nations in the world. In fact, the phenomenon of corruption has existed in society for a long time, but it has only attracted world attention since the end of the second world war. In Indonesia, the phenomenon of corruption has existed since Indonesia was not yet independent. One of the evidences that shows that corruption has existed in Indonesian society during the colonial era is the tradition of giving tribute by several groups of people to local authorities.

In Indonesia itself, the practice of corruption is so severe and acute. Many pictures of corrupt practices have been exposed to the surface. In this country itself, corruption is like a malignant cancer that spreads to the cells of public organs, infecting high state institutions such as the legislature, executive and judiciary to the village.

Granting regional autonomy as widely as possible means granting authority and discretion to the regions to manage and utilize regional resources optimally, so that irregularities and diversions do not occur, the granting of such broad authority and discretion must be followed by strong supervision. Although the emphasis on autonomy is placed at the Regency / City level, in essence this independence must be started from the lower level government level, namely the village.

Act No.6 of 2014 concerning Villages very clearly regulates Village Government, which states that a village is a legal community unit that has territorial boundaries that are authorized to regulate and manage the interests of

\footnotetext{
${ }^{1}$ KUHAP Lengkap, Bumi Aksara, Jakarta, 2004, p. 5

${ }^{2}$ M. Yahya Harahap, Pembahasan permasalahan dan penerapan KUHAP; Penyidikan dan penuntutan (edisi kedua), (Jakarta : Sinar Grafika, 2003 ), p. 101.
} 
local communities which are recognized and respected in the government system of the Unitary State of the Republic of Indonesia. ${ }^{3}$

It is believed that the village government is better able to see the priority needs of the community than the district / city governments which actually have a wider scope of problems. For this reason, rural development must be carried out in accordance with the problems faced, the potential they have, the aspirations of the community and the predetermined rural development priorities.

One form of government concern for rural development is the special development budget that is included in the Village Revenue and Expenditure Budget (APBD) for rural area development.

Village Fund Allocation plays an important role and is the main key to the success of village autonomy. The effectiveness and efficiency of distributing the Village Fund Allocation from the Regency / City Government to the Village Government as well as the utilization of village funds are very important for village development. In addition, many villages also have certain limitations, especially in government organizations, so that this will also affect the management of village funds.

The purpose of village funds distributed to village communities includes helping to overcome economic problems in the village, including reducing poverty, reducing unemployment, inhibiting the rate of urbanization and reducing inequality, helping to empower the economy of rural communities, helping equitable development and results, building infrastructure and creating new job opportunities and opportunities, In addition to using it for village development, but also for building human resources (HR) in the village such as carrying out coaching, guidance and assistance, and monitoring that is more orderly and interconnected, strengthening coordination, consolidation, and synergy with the implementation of programs that are priorities for village development from the central, regional, sub-district government levels to the village itself, Build infrastructure and public facilities services and empower and develop the economy in the village.

Misuse of village finances such as misuse of Village Fund Allocation is an act that is prohibited from being carried out by village officials. If this is done, then the person concerned will be subject to administrative sanctions in the form of an oral warning and / or a written warning. In the event that administrative sanctions are not implemented, a temporary dismissal will be taken and may be continued with dismissal.

In addition, this act is also a criminal act of corruption as regulated in Act No. 31 of 1999 concerning Eradication of Corruption Crime ("Act No. 31/1999") as amended by Act No. 20 of 2001 concerning Amendments to Act No. 31 of 1999 concerning Eradication of Corruption, where there is a criminal threat for a person who misuses his / her authority which results in a loss to state finances.

The community can make reports or complaints to the local Village Consultative Body (BPD) as well as to the Supra Villages Government, regarding the object of activity and the estimated value of the misused losses. In the

\footnotetext{
3. Act No 6 of 2014 on Villages
} 
reporting or complaint, it is necessary to be accompanied by a concrete explanation regarding the object of the activity which is suspected of fraud.

Village fund corruption has occurred in the jurisdiction of the Tasikmalaya Police, with the National Police Report No: LP / 193 / X / 2018 / SPKT.Tgl. October 30, 2018. The main case is that in 2017 Cipakat village, Singaparna District, Tasikmalaya Regency received phase II village funds sourced from the 2017 State Budget funds, then there was an application that applied for a community hall of Rp. 20,000,000.00 (twenty million rupiah) and for equipment of Rp. $100,000,000.00$ (one hundred million rupiah), from the second phase of funds in 2017, it is used to pay land and building tax arrears for residents of Cipakat Village, Singaparna District, Tasikmalaya Regency.

If indeed the community has strong evidence and can be accounted for in front of the law for the alleged misappropriation of village funds (corruption), then the community has the right to report the person to law enforcement officials regarding the follow-up process by carrying out an investigation, then it is felt that everything is then continued with the investigation.

Based on this, this study aims to: identify and analyze process investigations into the corruption crime of village funds in Tasikmalaya Regency, the obstacles encountered and what solutions the investigators took.

\section{Methods}

The approach method using juridical research in this study means that this research is viewed from the point of view of legal science and written regulations related to the Investigation Process against Corruption in Villages Fund in Tasikmalaya Regency. The specification in this study is an analytical description which aims to determine the Investigation Process against Corruption in Villages Fund in Tasikmalaya Regency. The data collection method used is library research and field studies. The data obtained were collected and compiled systematically and then conducted a qualitative data analysis based on the discipline of law and assisted by other social sciences, which was then applied in the form of thesis writing.

\section{Result and Discussion}

\subsection{Process Investigations Into Criminal Acts Of Corruption In Village Funds In Tasikmalaya Regency}

A suspect is an object of examination that can be subject to a variety of actions permitted under the procedural law, even though in the end it is not sufficient to prove the suspect's guilt. Such a situation cannot be completely avoided, because it is precisely with these actions that it is possible to know whether or not someone's suspicion of having committed a criminal act is true.

With the report, the Police will carry out a series of investigative actions to find and find an event that is suspected of being a criminal act of detention in order to determine whether or not an investigation can be carried out in a manner 
regulated by law. After an investigation is carried out and a criminal act is found, it is upgraded to an investigation, namely a series of actions by the investigator in terms and according to the manner stipulated in law to seek and collect evidence, which by means of that evidence sheds light on the criminal act that occurred and in order to find out the suspect.

Investigation activity is to find and collect evidence so that the criminal act found becomes clear and in order to find and determine the perpetrator, this activity must be in accordance with the applicable law. The final result of an investigative activity is that the case file has been perfect in terms of all aspects, perfect in terms of completeness of the file, as well as in terms of juridical and completeness of the requirements of evidence, as well as in terms of the application of the examination relating to the material legal content suspected to the suspect, if the results of the investigative examination do fulfill the elements of the formulation of the criminal act suspected and which will be accused of him. If everything is declared complete, the case file is submitted to the Public Prosecutor (Submission of the first stage case file).

It is very important to pay attention to the thoroughness and perfection of the investigative examination, professional investigators are expected to produce a perfect case file that is in accordance with the Criminal Procedure Code (KUHAP).

In carrying out their duties, investigators are obliged to uphold the applicable law. For this reason, the investigator prepares an official report on the implementation of the action (Article 75 KUHAP) concerning: Examination of suspects; Arrest; Detention; Search; Home income; Confiscation of objects; Letter checking; Witness examination; Examination of the scene; Implementation of Court Orders and Decisions; Implementation of other actions in accordance with KUHAP.

Based on the facts that have occurred, the existing evidence and the statements of witnesses, experts and the statements of the suspects, it can be concluded that there has been an allegation of Corruption in the Village Fund Phase II of FY 2017 that occurred in Cipakat Village, Singaparna district, Tasikmalaya regency, which initially applied for Village Fund Phase II of FY 2017, was partly not used in accordance with the submission, namely for Community Hall Rehab and Equipment Procurement but based on the policy of the suspect ADE GANI Bin (late) H. ADANG SOLEH who used part of the Village Fund Phase II of FY 2017 is not in accordance with its designation then if it is related to the results of the calculation of State financial losses carried out by the Inspectorate of Tasikmalaya Regency and obtained State Financial Losses of Rp. 129,469,041, (one hundred twenty nine million rupiah four hundred sixty nine thousand forty one rupiah) and linked to the statement of the suspect ADE GANI Bin (late) $\mathrm{H}$. ADANG SOLEH who at that time the suspect ADE GANI Bin (late) H. ADANG SOLEH was exercising his authority as the Head of Cipakat Village based on the District Head Decree. Tasikmalaya Number: 141.1 / Kep.500-DPMDPAKB / 2017, dated 18 December 2017 concerning the Appointment of the Head of Cipakat Village, Singaparna district, Tasikmalaya regency as the Head of Cipakat Village, 
Singaparna district, Tasikmalaya regency, then fulfilled the element of the alleged Corruption Crime. The suspect ADE GANI Bin (late) H. ${ }^{4}$

\subsection{Obstacles Encountered In Investigating Criminal Acts Of Corruption In Village Funds}

As for the obstacles encountered in the investigation, namely : The suspect did not provide clear information; Witness statement does not support the implementation of the investigation; and The evidence that will be submitted is incomplete.

According to the theory of the operation of law in society, that the effectiveness of a law is determined by 5 (five) factors, namely: 5

a. The legal factor itself (Law)

b. Law enforcement factors, namely the parties who form or implement the law

c. Factor of means or facilities that support law enforcement.

d. Community factors, namely the environment where law it applies or applies.

e. Cultural factors, namely as a result of work, creativity and taste based on human initiative in social life.

\subsection{The Solution Is To Deal With Obstacles In Investigating Criminal Acts of Village Funds Corruption At The Tasikmalaya Police}

Several things that must be considered to overcome obstacles in investigating criminal acts of corruption in village funds are as follows: 6

a. The suspect must provide information to the investigator honestly and clearly regarding the sequence of events and objects of the corruption crime and where it can be used as evidence to reveal the corruption crime of village funds.

b. Witnesses must be able to cooperate with investigators in providing honest and complete information, so as to make it easier for investigators to uncover criminal acts of corruption in village funds

c. Investigators must be able to find and collect evidence, at least 2 (two) pieces of evidence

The effectiveness and success of law enforcement depends on the three elements of the legal system according to enforcement theory, namely the substance of the law, the structure of law, and the legal culture.

In accordance with the results of the research that the author conducted by presenting cases in the Tasikmalaya Police jurisdiction with The suspect ADE GANI bin (late) H. ADANG SOLEH. When connected with law enforcement theory as follows: ${ }^{7}$

a. Substance of the Law

\footnotetext{
${ }^{4}$ Tasikmalaya Police, 2017, Kasus tindak pidana korupsi Dana Desa

5 https://suduthukum.com/2018/01/teori-bekerjanya-hukum.html

${ }^{6}$ Bripda Agus Yusup P, Personal Interview, Member of Reskrim, Tasikmalaya Police, on June 2, 2002

${ }^{7}$ File:///E:/KETIKAN\%202018/AKPOL/S2\%202019/teori\%20lawrence\%20m\%20friedmen.htm
} 
The substance of law can be said as norms, rules, and real human behavior in that system, in the substance of the law there is the term "product", which is a decision that has just been compiled and has just been made which here emphasizes a law that will be made create if through events first.

b. Legal structure

Legal structure, namely the framework of a permanent form of the legal system that keeps the process within its boundaries. The structure consists of: the number and size of the courts, their jurisdiction (the types of cases examined and the procedural law used), including in this structure the arrangement of the legislative body.

c. Legal culture

This legal culture is also interpreted as an atmosphere of social thought and social forces that determine how laws are used, avoided, or abused.

\section{Closing}

\subsection{Conclusion}

a. Proses investigations into criminal acts of corruption in village funds in Tasikmalaya Regency

With this report, the Police will carry out a series of investigative actions to find and find an event that is suspected of being a criminal act of corruption in order to determine whether or not an investigation can be carried out in a manner regulated by law. After an investigation is carried out and a criminal act of village fund corruption is found, it is upgraded to an investigation, namely a series of actions by the investigator in terms and according to the manner stipulated in law to seek and collect evidence, which with this evidence makes clear about the criminal act of fund corruption. The village that happened and in order to find the suspect. The investigation process, extended detention, searches and confiscations.

b. Constraints faced in conducting criminal investigations at the Tasikmalaya Police: The suspect did not provide clear information; Witness statement does not support the implementation of the investigation; The evidence that will be submitted is incomplete.

c. The efforts made in overcoming obstacles are as follows: The suspect must provide information to the investigator in an honest and clear manner regarding the series of incidents and objects of corruption and where it can be used as evidence to reveal coruption in village funds; Witnesses must be able to cooperate with investigators in providing honest and complete information, so as to make it easier for investigators to uncover criminal acts of corruption in village funds; Investigators must be able to find and collect evidence, at least 2 (two) pieces of evidence 


\subsection{Suggestion}

- Investigators in conducting investigations into criminal acts at the Tasikmalaya Police must comply with the Criminal Procedure Code

- Investigators must really pay attention to the presumption of innocence in every person who has been suspected of committing a crime, before the judge decides with permanent force.

- In carrying out their duties, investigators must pay attention to the Criminal Procedure Code, so that they do not make mistakes in determining the suspect

\section{Bibliography}

M. Yahya Harahap, 2003, Pembahasan permasalahan dan penerapan KUHAP; Penyidikan dan penuntutan (second edition), Jakarta: Sinar Grafika

Polres Tasikmalaya, 2017, Kasus tindak pidana korupsi Dana Desa

M. Ali Mansyur, 2010, Mewujudkan Masyarakat Anti Korupsi Melalui Pendekatan Preventif dan Kuratif di Indonesia, Jurnal Khaira Ummah

Miftakhul Khobid, Gunarto, Lathifah Hanim, 2018, Analisa Kebijakan Formulasi Hukum Pidana Dalam Penanggulangan Tindak Pidana Korupsi, Jurnal Khaira Ummah

Mustaqhfirin, Irwanto Efendi, 2015, Tinjauan Yuridis Terhadap Implementasi Pidana Korupsi Dalam Upaya Mengembalikan Keuangan Negara, Journal IJLR

Act No. 6 of 2014 on Villages

2004, KUHAP Lengkap, Jakarta: Bumi Aksara

File:///E:/KETIKAN\%202018/AKPOL/S2\%202019/teori\%20lawrence\%20m\%20 friedmen.htm

https://suduthukum.com/2018/01/teori-bekerjanya-hukum.html

Bripda Agus Yusup P, Personal Interview, Member of Reskrim, Tasikmalaya Police, on June 2, 2002 